Arab World English Journal (AWEJ) Special Issue on Covid 19 Challenges April 2021

DOI https://dx.doi.org/10.24093/awej/covid.11

Pp, $147-159$

\title{
English Language Teaching in Saudi Arabia in Response to the COVID-19 Pandemic: Challenges and Positive Outcomes
}

\author{
Reem A. Al-Samiri \\ English Language Institute, \\ University of Jeddah, Jeddah, Saudi Arabia \\ Email: ralsamiri@uj.edu.sa
}

Recived: 3/6/2021

Accepted: 4/8/2021

Published:4/26/2021

\begin{abstract}
The pandemic of 2020 was a watershed moment for all educators worldwide as schools and universities were forced to close their doors to avoid the spread of COVID-19. Thus, a new movement towards widespread e-learning emerged with unknown consequences for learners and educators alike. The situation in Saudi Arabia was no exception. The purpose of this study is to explore how English as a foreign language (EFL) teaching and learning at the tertiary level in Saudi Arabia was impacted negatively and positively by the move to online learning. It reviews research published since the onset of the pandemic, with a specific focus on English language teaching at Saudi universities, to analyze the challenges faced by Saudi EFL teachers and learners since the shift to e-learning. One of the biggest challenges observed was students' lack of motivation, which upon further review was found to be linked to other contributing factors, such as technological issues, inapt learning environments, and students' mental health. This paper also examines the unforeseen positive outcomes resulting from the digital transformation, including the benefits of the flexibility of place and time and promotion of particular language skills. The current research synthesis will help contribute to the knowledge of online English teaching in the Saudi context.
\end{abstract}

Keywords: COVID-19 pandemic, distance learning, e-learning, English as a foreign language (EFL), English language teaching (ELT), remote learning, Saudi university students

Cite as: Al-Samiri, R. A. (2021). English Language Teaching in Saudi Arabia in Response to the COVID-19 Pandemic: Challenges and Positive Outcomes. Arab World English Journal (AWEJ) Special Issue on Covid 19 Challenges (1) 147-159. DOI: https://dx.doi.org/10.24093/awej/covid.11 


\section{Introduction}

The global community was hit hard by the worldwide pandemic produced by the Novel Coronavirus (COVID-19) disease, which caused the whole world to come to a halt in 2020. In such unprecedented times, educators worldwide were faced with the necessity of migrating to online teaching. In-person learning became too much of a risk for contracting and spreading the disease. This sudden, unprecedented shift comes with unknown consequences for educators, as the world is still observing its effects. Thus, this article aims to provide an overview of the educational scene in the Saudi English as a Foreign Language (EFL) context during the pandemic and delineate the challenges and positive outcomes of online learning in Saudi Arabia amidst the COVID-19 global pandemic. The following research questions guide the current review:

1. What challenges do university students and instructors face with online learning and teaching of EFL during the COVID-19 pandemic?

2. What are the perceived advantages to online learning during the COVID-19 pandemic?

These questions will be answered through a review of the most recent literature published in the field of EFL and language education since the onset of the pandemic in 2020. Search words such as "English language," "Saudi universities," "COVID-19," and "EFL" were used to carry out the investigation of the topic. The subsequent sections discuss Saudi Arabia's response to the pandemic, how schools and universities proceeded with education after closures, and previous studies on e-learning in the Saudi context. Following that is a consideration of the most prominent challenges Saudi university EFL educators and students face in online learning, as well as positive outcomes observed as a result of the switch to online learning.

\section{Literature Review}

\section{KSA's Response to the Pandemic}

The Kingdom of Saudi Arabia (KSA) was evident in its humanitarian message since the beginning of the pandemic. That is, that human life is more valuable than anything, regardless of race, gender, religion, or nationality. Therefore, within the first few days of March 2020, there was an immediate response to shut down anything that would compromise people's health and well-being, including schools, universities, and public and private institutions (Nurunnabi, 2021).

However, this physical closure of buildings did not impede the country's ambitious goals and aspirations. Instead, it only increased them. As a response to the closures, all Saudi sectors turned to digital technologies to help maintain services while thwarting the disease's spread (Hassounah et al., 2020), including education. In a brief timeframe, the whole country began the transition to remote learning environments, whether it was televised on select channels or communicated through various online platforms: Telegram, Zoom, Teams. WebEx, and Blackboard. However, the situation at the beginning of the pandemic was far from ideal. Many students and teachers were not equipped with the necessary digital readiness or the internet bandwidth to connect to these online platforms. Nonetheless, they rose to the occasion and gradually adjusted to the new normal in education. 
Arab World English Journal (AWEJ) Special Issue on Covid 19 Challenges April 2021

English Language Teaching in KSA in Response to the COVID-19

Al-Samiri

\section{Schools and Universities in KSA}

Beginning the 2020-2021 academic school year, the Saudi Ministry of Education launched a national Digital Teaching Platform (DTP) called Madrasati (meaning my school). The purpose was to provide a unified platform for delivering online instruction to over six million students in Saudi public schools, from first to twelfth grade (Oraif \& Elyas, 2021). With the initiation of the new school year, educators began to recover learning that was missed during the pandemic and continued to cover new learning material. Middle- and high-school students attended classes online during reserved morning hours, whereas elementary school students attended classes in the afternoon. These efforts ensured that each level had an allotted learning time and reduced the internet traffic congestion caused by too many users at a time. The afternoon hours preserved for elementary school students also allowed parents to assist their young children in attending their online classes and support their learning (Oraif \& Elyas, 2021).

On the other hand, Saudi universities were naturally better prepared to transition to the online learning environment, as most Saudi universities had already implemented digital communication and learning tools. For example, university students are set up with an official email account as soon as they enroll; therefore, university students' communication with their institutions was not interrupted. Also, most Saudi universities utilized Blackboard®, a Learning Management System (LMS) designed to deliver both synchronous and asynchronous modes of learning. However, this software was not used extensively and served a supplementary role prior to the pandemic, and its e-learning users are still discovering its features.

\section{E-Learning of English in KSA}

In discussing technology use to deliver educational material, many terms are widely used, such as e-learning, online learning, electronic learning, digital learning, and technologyenhanced learning. These terms are all used to describe "a set of technology-mediated methods that can be applied to support student learning and include elements of assessment, tutoring, and instruction" (Wheeler, 2012, p. 1109). In other words, the primary and only method of delivering educational content and instruction is through digital and online tools. This could either be synchronous (i.e., teaching occurs live with students and instructors both present online in real-time) or asynchronous (i.e., the content and instruction are available for the students to access any time via recordings of the lessons or independent online activities).

Many previous studies have investigated the effectiveness of implementing technology in EFL learning in KSA universities. However, these studies approached technological tools as supplementary to face-to-face instruction in a method called blended learning, which is defined as "any formal education program in which a student learns at least in part through online learning" (Maxwell, 2016, para. 3). That is, only part of the instructions occurs online, whereas the rest occurs in person. This method has shown positive results in learning English in KSA. For example, Alsowayegh et al. (2019) at King Abdulaziz University found that using online activities (i.e., watching videos related to the lesson and participating in discussion forums) in addition to in-person instruction improved university EFL learners' listening and speaking skills. Other studies surveying university EFL students' perceptions of employing the blended learning model in their English acquisition show positive attitudes towards this method (Al-Jarf, 2007; Alowedi, 2020; Bukhari \& Basaffar, 2019; Gulnaz et al., 2019). 
Arab World English Journal (AWEJ) Special Issue on Covid 19 Challenges April 2021

English Language Teaching in KSA in Response to the COVID-19

Al-Samiri

Nevertheless, these studies only consider technology's role as a supplement to face-toface instruction, not as a replacement which is the case during the pandemic. The blended learning model differs from the e-learning model in that the former offers some in-person instruction, whereas the latter occurs entirely online, making the results incomparable and should be discussed separately.

\section{Challenges in the Online Teaching of English During the Pandemic}

Issues in English language teaching (ELT) have existed long before the COVID-19 pandemic. Though, existing problems only exacerbated with the sudden shift to online learning and the adjustments entailed. One of the most prominent concerns discussed in ELT is language learners' motivation to learn (Al-Hoorie, 2017). Language educators in the Saudi context have widely observed the lack of student motivation (Elyas \& Al-Grigri, 2014), likely caused by students' low proficiency (AlMaiman, 2005), but also subject to alternative factors (MacIntyre, 2002). Previous literature suggests that online learning environments are more engaging and conducive to increasing learner motivation (Kim \& Frick, 2011). However, distance learning is also "sensitive to situational conditions" (Hartnett et al., 2011, p. 20), influenced by external factors, such as time constraints, grades, and the students' learning environment. The pandemic further compounds these issues. In fact, a recent survey of over one thousand academic English instructors in 99 countries revealed that student motivation during the pandemic was among the respondents' top concerns (Wright, 2021).

A study conducted by ur Rahman (2020) surveying fifty English language instructors across the kingdom about their perceptions of online learning during the COVID-19 pandemic reported that $68 \%$ of the respondents believed that students are less motivated to learn online. This lack of motivation is not necessarily due to the online learning environment itself. Other literature cites the significant causes for student demotivation during the pandemic are respectively: being socially isolated, having a weak internet connection, enduring distractions at home, and not being able to achieve class objectives (Hernández \& Flórez, 2020). As almost all KSA schooling has moved online, students are obliged to attend school from their homes where they feel disconnected from their peers or distracted by siblings and other family members who are also learning or working remotely. Only those who need to attend practical training or laboratories continue to participate in face-to-face learning.

An additional reason for students' demotivation could be due to mental health issues, given that motivation and anxiety are highly correlated (MacIntyre, 2002). Studies revealed that many Saudis suffered from some level of anxiety, depression, and post-traumatic stress disorder due to the pandemic, especially in its initial phase (AlKhamees et al., 2020; Joseph et al., 2020). Learning during the COVID-19 pandemic can be very stressful on students due to the sudden changes surrounding them and anxiety over the disease itself (Elsalem et al., 2020; Ghazi-Saidi et al., 2020). As a result, students may suffer psychological distress caused by the fear of halting their academic progress (Hasan \& Bao, 2020). Although students and educators have managed to carry on with the educational process, they are doing so in less-than-optimal conditions and numerous barriers to overcome, all of which could affect motivation.

Digital readiness is another issue put forth by the pandemic of 2020. Digital readiness can be defined as "the degree to which people succeed or struggle when they use technology to 
try to navigate their environments, solve problems, and make decisions" (Horrigan, 2016, p.2). The switch to remote learning took the world by surprise and left many students and educators unprepared for the new tasks they had to take on. Al-Nofaie (2020) carried out a Blackboard readiness survey with 25 students majoring in the English language department at Taif University. The findings indicate students' lack of digital readiness and technology skills. The author also mentions instructing her students on how to download PDF files and write notes on them, which demonstrates the need to support students during difficult times. Indeed, in many cases, English language instructors have had to take on a technical support specialist's role, teaching students, among other things, how to download, upload, and share their work. Especially when working with language learners, those with lower English proficiency levels may face additional difficulties accessing digital technology, as most of the technology is available in English (Sugarman \& Lazarin, 2020).

Furthermore, the availability of appropriate technology and reliable internet connection (on both the students' and teachers' end) is the only way students can access educational content and online courses. Therefore, internet connectivity and bandwidth influence learners' online experiences significantly, seeing that their learning experiences are dependent on the reliability of their internet connection (Al-Nofaie, 2020). Qualitative interviews conducted by Bin Dahmash (2020) with 12 EFL university students at King Saud University revealed that students faced technical problems while attending their classes on Blackboard, from incompatible devices, sound interruption to being logged out by the platform. These issues increased at certain times in the day with increased internet traffic accessing the platform simultaneously. Likewise, Mabrook's (2020) survey of 20 EFL learners at Onaiza colleges found that $64.3 \%$ of the respondents indicated that they faced "repeated disconnections," interfering with their learning and online exams. These interruptions caused by slow or weak internet connection affect the quality of the online learning experience. They may also negatively impact learning, as they could lead to student frustration and demotivation (Hashim et al., 2018).

Additionally, there is the issue of poor technical support. Due to a multitude of students and faculty needing support at any given time, students do not receive help when they need it (Ali \& Abdalgane, 2020). Besides, students with disabilities face accessibility issues and lack the required support they received while attending their educational institutions in person. For example, those with visual impairments will have trouble seeing the digital whiteboard, reading material that the instructor posts, or participating in the classroom chat. They need access to voice-to-text software, which still does not support all digital platforms and file formats. Similarly, students with hearing loss do not always have access to closed captioning or subtitles of the oral or video lectures. These accessibility issues for students with special needs leave them excluded and prevent them from taking full advantage of online learning (Madhesh, 2021).

It is worth mentioning here that in KSA's general education, one of the most impressive achievements by the Saudi Ministry of Education was creating 23 educational television channels called $i E n$ for those who do not have access to the internet. These channels include interpretations using Saudi sign language for students who are hearing impaired. They have also created three channels for special education students with learning disabilities. These instructional accommodations help mitigate some of the accessibility concerns of distance learning for children with special needs. Yet, similar services are deficient at the university level. 
On the other hand, lack of visual input during online learning is a significant challenge for EFL learners. Due to cultural constraints and respecting users' privacy, turning on cameras and visibly appearing in the virtual classroom is not required of students and instructors, especially at the tertiary level. However, ELT theory and evidence argue for the importance of non-verbal input and facial gestures in language learners' development. Visual cues are crucial for communicating critical information that conveys the overall meaning of the verbal message (Gregersen \& MacIntyre, 2017). Thus, the listener's loss of the speaker's visual input in an online language lesson is a disadvantage to EFL students. For that reason, many studies of online learning during the pandemic suggest the preference for face-to-face communication with peers and instructors in the Saudi EFL context (Al-Jarf, 2020; Al-Nofaie, 2020). In fact, participants in Dahmash's (2020) qualitative focus groups mentioned that they preferred in-person classes due to "the absence of the eye contact between themselves and the instructor" (p. 228).

Assessments are also another challenge with ELT being carried out remotely for various reasons. First, many language instructors face the issue that there is no guarantee that what the students are submitting is their original work. Despite the availability of anti-cheating software and plagiarism tools, not all instructors are adequately trained to apply them, or students bypass them by using various academic dishonesty methods.

Ali and Abdagane (2020) noted that one of the obstacles faced in the online teaching of English is the "ease of penetration of the content of the test" (p.12). They mention several methods to reduce cheating, such as using a plagiarism checker to check the students' written answers, paraphrasing the content of objective type questions, displaying single questions in random order, and reducing the allotted time for the test. Nevertheless, without being physically present or applying surveillance software (which would violate students' privacy), there is no guarantee that the student is completing the assessment on his/her own. It also makes it more troublesome to evaluate students' learning progress. For example, Mabrook (2020) found that students used a second device during exams to search for answers online or simply copy and paste responses from other sources. Due to these issues in evaluating students, remote assessments do not depict students' development accurately.

Moreover, online learning and teaching are more time-consuming than in-person classes, creating yet another challenge. In a survey of academic English teachers worldwide, Wright (2021) showed that only $10 \%$ of English language teachers spent most of their teaching time online before the pandemic. Now, however, $55 \%$ of the teachers surveyed spend $100 \%$ of their teaching time online. In addition to teaching online, language instructors also prepare content, create materials, send and reply to emails, post assignments for students, and correct students' work online, to name a few. As a result, language teachers spend between 10 to 12 hours in front of a screen daily (Hernandez \& Florez, 2020). Similarly, in Mabrook's (2020) survey of Saudi EFL university students, $85.7 \%$ claimed it takes them more time to prepare for online lectures than it does for in-person classes. It is also disconcerting because, as Shaibani (2020) suggests, the longer time spent online, especially using mobile devices, was highly correlated with academic procrastination and social media addiction. Furthermore, long hours of screen time and online communication cause many users to feel exhausted and drained from what has come to be known as Zoom Fatigue (Wiederhold, 2020). 
There are also issues with learning platforms. In addition to Blackboard LMS, students and instructors have utilized alternative applications and software, yet they come with privacy and security issues. One of those is WhatsApp, a mobile application that allows its users to send text messages, photos, videos, voice notes, and even make calls with family and friends for free via the internet. A study by Alabasi and Alghamdi (2019) reported that WhatsApp is one of the most widely used applications by university EFL students who perceive the application as helping them learn reading, writing, and grammar. However, many privacy concerns have surrounded the application because of how users' data is being used and shared. Recently, due to an update in January 2021 by WhatsApp's owner company, Facebook, requiring users to share even more of their and contact information, most universities directed faculty and staff to switch over to Signal-a similar functioning app that offers more protection of data (Tashkandi, 2021).

The videoconferencing application, Zoom, faced similar concerns. Before the COVID-19 pandemic, hardly anyone had used Zoom for teaching, but as soon as schools went virtual, almost everyone was using it at first. Zoom offers various compelling features for teachers, such as live audio and video chat, a digital whiteboard, screen sharing, and uploading instructional materials. University students also found it helpful. Alfadda and Mahdi (2021) found a positive correlation between Saudi EFL university students' use of Zoom and their acceptance and perceived usefulness of the technology. Nevertheless, security vulnerabilities were discovered after a series of Zoombombings, in which an individual attends "a Zoom session who has not been invited, with the potential for overt disruption" (Fudge \& Williams, 2020, p. 197). Another problem was Deepfakes, which is "the imposition of someone else's face on a different person's body in video format using Artificial Intelligence algorithms" (p.197). As a result, most Saudi universities warned their faculty against using Zoom for teaching and web conferencing and requested that they replace it with a more secure alternative, such as Blackboard LMS, even though it does not offer all the same convenient features.

\section{The Positive Outcomes of Online Teaching During COVID-19}

Despite the drawbacks of the online instruction of English, many positive aspects have surfaced. One of the most significant advantages is the flexibility that online learning affords. Remote learning offers flexibility for students and teachers to attend classes anywhere and anytime (if learning asynchronously). It even provides versatility in the type of devices and software used by students and instructors. Aljaber's (2021) investigation of Saudi university students revealed that they are most likely to use their mobile phones in e-learning environments, making it easier to access their lessons and learning materials. The author also maintained that virtual learning environments allow "students the freedom to study and finish the coursework anytime, anywhere" (p.138). For example, Mabrook (2020) points out that EFL students attended while at work, in the car, while seated with family, or from the comfort of their bed, even though this is not necessarily desirable. This flexibility has also saved students the time they spent commuting to and from their university campuses (Al-Jarf, 2020; Bin Dahmash, 2020). Surprisingly, even instructors stranded across borders - due to quarantine mandates and air travel lockdown - could teach from different countries, sometimes numerous time zones apart (Yandell, 2020). Thus, online learning during the pandemic has removed the physical constraints of space and time while paving the way for a new learning approach that transcends these barriers. 
One of the other benefits observed as a result of the switch to the online instruction of English is that students who were too shy to speak up in front of a large class might be more willing to speak in front of a screen from the comfort of their home. For instance, Khafaga's (2021) survey of 311 EFL university students from five major Saudi universities revealed that attending classes via Blackboard (instead of in-person) helped learners overcome their shyness in participating in class discussions. Similarly, online language learning has been claimed to boost introverted students' confidence in class (Hakim, 2020) and promote peer interaction (Al-Nofaie, 2020). The (partial) anonymity afforded by e-learning provides a safe space that contributes to reducing students' anxiety around speaking a foreign language.

The switch to online instruction has also accelerated the development of new skills in both language students and their instructors, seeing as the sudden shift has forced many to tread on uncharted territories. Among the new skills implemented by English language teachers for the first time since the pandemic are: teaching online, delivering presentations online, providing online practice for students, using electronic versions of coursebooks, and carrying out online assessments (Wright, 2021). Likewise, the virtual learning environment helped improve EFL students' language skills, especially in listening and speaking (Khafaga, 2020; Hernandez \& Florez, 2020) and their online searching skills (Bin Dahmash, 2020). Despite the difficulty many faced in adapting to online environments, the new experiences spurred novel skills acquisition and honed existing expertise.

Along the same lines, the move to digital learning has resulted in the incidental learning (i.e., learning without the intention of learning) of English which occurs through exposure to the language informally. Because English is the most common language used online, with $25.9 \%$ of online content being in English (Statista, 2020), EFL learners encounter more English outside their language lessons than they would in a face-to-face classroom. Also, Alqarni (2020) argues that Saudi EFL learners' use of the internet promotes their informal acquisition of the language because students have access to content that piques their interests, such as music, movies, YouTube videos, and videogames. Hence, online learning may prove to be beneficial for students' informal learning of English.

Furthermore, the need for novel skills for online teaching and learning created a universal need for professional development opportunities. With the surge of COVID-19 cases and the increased quarantine restrictions, there was a boom in online training and educational material. The result was universal access to a wealth of knowledge through online webinars, conferences, courses, and workshops - primarily free of charge (Shin \& Borup, 2020). It has never before been this convenient to attend educational and training events in different places, without being limited to choosing only one. Saudi universities all participated in these events and provided access to university affiliates and non-affiliates alike. Additionally, many professors, educators, libraries, and even publishers offered free access to their materials to ensure that while the whole world comes to a standstill, education does not.

\section{Discussion}

This paper reviewed and synthesized over 40 recently published research concerning the online teaching of English as a foreign language in the Kingdom of Saudi Arabia during the COVID-19 pandemic by highlighting the challenges and benefits discussed in the literature. The 
current research on how distance learning influences EFL learning and teaching at the tertiary level implies several vital points. First, learners' motivation is at risk. Although e-learning benefits students who struggle with shyness or foreign language learning anxiety by promoting their classroom interaction, many students lack the motivation to attend classes or participate in online activities. Part of this lack of motivation could also be due to complications students face with internet connectivity that affect the quality of lesson delivery. The other reason could be that the students are attending lessons in less-than-optimal learning environments.

Remote learning has allowed students to join their virtual classrooms wherever they may be. However, the flexibility of distance learning is a double-edged sword. On the one hand, it removed the physical limitations of space and time, providing access to learning and development opportunities worldwide and saved the time it takes to commute to and from university campuses. On the other hand, it also allows for more distraction from learning. The home environment is replete with disruptions, especially with other family members working and learning from home. Furthermore, the absence of separation between home and school environments makes it harder for students to distinguish between leisure time and learning time.

The switch to online learning also highlighted several other issues that hinder students' progress. One of the problems that surfaced is insufficient digital readiness skills in students and, sometimes, teachers, which is further compounded by the shortage of technical support. The various advantageous features of e-learning become inaccessible when its users cannot access and use them. Additionally, dealing with such issues and navigating online territories is timeconsuming for both learners and instructors.

Mainly related to language development, students need to have visual input of the spoken language. Not activating the use of video features during the lesson may undermine the development of their speaking and listening skills. Alternatively, students' vocabulary and research skills may improve due to the incidental learning that occurs while accessing the internet with all its English content. Nevertheless, assessing the development of these language skills online has proven to be a predicament that requires teachers to take extra precautions to help assure its validity.

\section{Conclusion}

In conclusion, educators and stakeholders must consider the issues mentioned above when examining the efficacy of e-learning in EFL and evaluating its usefulness and application after the pandemic finally comes to an end. Future research in this area should investigate the discrepancy in learner motivation between those who are more inclined to join in peer discussions online and those who feel less motivated to participate when classes are online. Also, there is a need for larger-scale studies to measure the academic EFL learning outcomes at the university level in Saudi Arabia.

\section{About the Author:}

Reem A. Al-Samiri is an assistant professor at the English Language Institute at the University of Jeddah, Saudi Arabia. She completed her Ph.D. in Curriculum and Teaching at the University of Kansas, USA, majoring in Teaching English to Speakers of Other Languages (TESOL). Her 
Arab World English Journal (AWEJ) Special Issue on Covid 19 Challenges April 2021

English Language Teaching in KSA in Response to the COVID-19

Al-Samiri

research interests include language learner/teacher identity, language teacher education, and transnational students' experiences in education. ORCID: https://orcid.org/0000-0001-7040-5802

\section{References}

Alabsi, K. M., \& Alghamdi, F. M. (2019). Students' Opinions on the Functions and Usefulness of Communication on WhatsApp in the EFL Higher Education Context. Arab World English Journal, Special Issue 1: Application of Global ELT Practices in Saudi Arabia. 129- 144 DOI: https://dx.doi.org/10.24093/awej/elt1.10

Alfadda, H. A., \& Mahdi, H. S. (2021). Measuring Students' Use of Zoom Application in Language Course Based on the Technology Acceptance Model (TAM). Journal of Psycholinguistic Research. https://doi.org/10.1007/s10936-020-09752-1

Al-Hoorie, A. H. (2017). Sixty Years of Language Motivation Research: Looking Back and Looking Forward. SAGE Open, 7(1), https://doi.org/10.1177/2158244017701976

Ali, R., \& Abdalgane, M. (2020). Teaching English Literacy in the Time of COVID-19 Pandemic in Higher Education: A Case Study in Saudi Qassim University. Multicultural Education, 6(5), 204-215. https://doi.org/10.5281/zenodo.4374526

Aljaber, A. A. M. (2021). The reality of using smartphone applications for learning in higher education of Saudi Arabia [Unpublished doctoral dissertation]. University of Glasgow.

Al-Jarf, R. (2007). Online Instruction and Creative Writing by Saudi EFL Freshman Students. Asian EFL Journal, 22. Available at https://www.asian-efl-journal.com/monthly-editionsnew/online-instruction-and-creative-writing-by-saudi-efl-freshman-students/

Al-Jarf, R. (2020). Distance learning and undergraduate Saudi students' agency during the Covid-19 Pandemic. Bulletin of the Transilvania University of Brasov, 13(62), 37-54. https://doi.org/10.31926/but.pcs.2020.62.13.2.4

Alkhamees, A. A., Alrashed, S. A., Alzunaydi, A. A., Almohimeed, A. S., \& Aljohani, M. S. (2020). The psychological impact of COVID-19 pandemic on the general population of Saudi Arabia. Comprehensive Psychiatry, 102. https://doi.org/10.1016/j.comppsych.2020.152192

AlMaiman, I. (2005). A study of seventh -grade Saudi students' motivation level to learn English as a foreign language, (Unpublished doctoral dissertation). University of Kansas. Available at http://search.proquest.com/docview/304990875/abstract/44DF25B67A324409PQ/1

Al-Nofaie, H. (2020). Saudi University Students' Perceptions towards Virtual Education During Covid-19 Pandemic: A Case Study of Language Learning via Blackboard. Arab World English Journal, 11(3), 4-20. https://doi.org/10.24093/awej/vol11no3.1

Alowedi, N. A. (2020). Saudi Electronic University a Role Model in Implementing Blended Learning; Exploring the Experience of Female Students in the Department of English Language and Translation. International Journal of English Language Education, 8(1), 113-130. https://doi.org/10.5296/ijele.v8i1.16685

Alqarni, M. S. (2020). Informal EFL Learning in Saudi Arabia and the Role of the Internet: An Ecological Perspective, (Unpublished doctoral dissertation). The University of Queensland.

Alsowayegh, N. H., Bardesi, H. J., Garba, I., \& Sipra, M. A. (2019). Engaging Students through Blended Learning Activities to Augment Listening and Speaking. Arab World English Journal (AWEJ) Special Issue on CALL (5), 267-288. https://doi.org/10.24093/awej/call5.18 
Arab World English Journal (AWEJ) Special Issue on Covid 19 Challenges April 2021

Bin Dahmash, N. (2020). 'I Couldn't Join the Session': Benefits and Challenges of Blended Learning amid COVID-19 from EFL Students. International Journal of English Linguistics, 10(5), 221-230. https://doi.org/10.5539/ijel.v10n5p221

Bukhari, S. S. F., \& Basaffar, F. (2019). EFL Learners' Perception about Integrating Blended Learning in ELT. Arab World English Journal (AWEJ) Special Issue on CALL, 5, 190205. https://doi.org/10.31235/osf.io/nmjf2

Elsalem, L., et al. Al-Azzam, N., Jum'ah, A. A., Obeidat, N., Sindiani, A. M., \& Kheirallah, K. A. (2020). Stress and behavioral changes with remote E-exams during the Covid-19 pandemic: A cross-sectional study among undergraduates of medical sciences. Annals of Medicine and Surgery, 60, 271-279. https://doi.org/10.1016/j.amsu.2020.10.058

Elyas, T., \& Al-Grigri, W. (2014). Obstacles to Teaching English in Saudi Arabia Public Schools: Teachers and supervisors' perceptions. International Journal of English Language Teaching, 89274, 74-89.

Fudge, T., \& Williams, L. (2020). Zoom in (but fasten your seatbelt). International Conference for Media in Education (iCoME) 2020: Diversity Education in ICT Advanced Society, Kobe, Japan (online). pp. 195-201. https://icome.education/wpcontent/uploads/2020/08/icome2020_programproceedings_final_v2.pdf

Ghazi-Saidi, L., Criffield, A., Kracl, C. L., McKelvey, M., Obasi, S. N., \& Vu, P. (2020). Moving from Face-to-Face to Remote Instruction in a Higher Education Institution during a Pandemic: Multiple Case Studies. International Journal of Technology in Education and Science, 4(4), 370-383. https://doi.org/10.46328/ijtes.v4i4.169

Gregersen, T., \& MacIntyre, P. D. (2017). Optimizing Language Learners Nonverbal Behavior: From Tenet to Technique. Bristol, England: Multilingual Matters.

Gulnaz, F., Althomali, A. D. A., \& Alzeer, D. H. (2019). An Investigation of the Perceptions and Experiences of the EFL Teachers and Learners About the Effectiveness of Blended Learning at Taif University. International Journal of English Linguistics, 10(1), 329-344. https://doi.org/10.5539/ijel.v10n1p329

Hakim, B. (2020). Technology Integrated Online Classrooms and the Challenges Faced by the EFL Teachers in Saudi Arabia during the COVID-19 Pandemic. International Journal of Applied Linguistics and English Literature, 9(5), 33-39. https://doi.org/10.7575/aiac.ijalel.v.9n.5p.33

Hartnett, M., St. George, A., \& Dron, J. (2011). Examining motivation in online distance learning environments: Complex, multifaceted and situation-dependent. The International Review of Research in Open and Distributed Learning, 12(6), 20-38. https://doi.org/10.19173/irrodl.v12i6.1030

Hasan, N., \& Bao, Y. (2020). Impact of “e-Learning crack-up" perception on psychological distress among college students during COVID-19 pandemic: A mediating role of "fear of academic year loss." Children and Youth Services Review, 118,1-9. https://doi.org/10.1016/j.childyouth.2020.105355

Hashim, H., Yunus, M. M., \& Embi, M. A. (2018). Learning through mobile: Exploring the views of Polytechnic ESL learners. TLEMC (Teaching and Learning English in Multicultural Contexts), 2(1), 56-62.

Hassounah, M., Raheel, H., \& Alhefzi, M. (2020). Digital Response During the COVID-19 Pandemic in Saudi Arabia. Journal of Medical Internet Research, 22(9). https://doi.org/10.2196/19338 
Arab World English Journal (AWEJ) Special Issue on Covid 19 Challenges April 2021

Hernández, S. S. F., \& Flórez, A. N. S. (2020). Online Teaching during Covid-19: How to Maintain Students Motivated in an EFL Class, 16(2), 157-171.

Horrigan, J. B. (2016). Digital Readiness Gaps. Pew Research Center. Available at https://www.pewresearch.org/internet/2016/09/20/digital-readiness-gaps/

Joseph, R., Lucca, J. M., Alshayban, D., \& Alshehry, Y. A. (2021). The immediate psychological response of the general population in Saudi Arabia during COVID-19 pandemic: A crosssectional study. Journal of Infection and Public Health, 14(2), 276-283. https://doi.org/10.1016/j.jiph.2020.11.017

Khafaga, A. F. (2021). The perception of blackboard collaborate-based instruction by EFL majors/teachers amid COVID-19: A case study of Saudi universities. Journal of Language and Linguistic Studies, 17(2), 1160-1173.

Kim, K.-J., \& Frick, T. W. (2011). Changes in student motivation during online learning. Journal of Educational Computing Research, 44(1), 1-23.

Maxwell, C. (2016, March 4). What blended learning is-And isn't. Blended Learning Universe. Available at https://www.blendedlearning.org/what-blended-learning-is-and-isnt/

Mabrook, A. M. (2020). Distant Learning; Its impact to EFL Students Due to COVID-19, Onaizah Colleges, Saudi Arabia. International Journal of Contemporary Applied Researches, 7(8).

MacIntyre, P. D. (2002). Motivation, anxiety and emotion in second language acquisition. In P. Robinson (Ed.), Language Learning \& Language Teaching (Vol. 2, pp. 45-68). John Benjamins Publishing Company. https://doi.org/10.1075/1llt.2.05mac

Madhesh, A. (2021). Full exclusion during COVID-19: Saudi Deaf education is an example. Heliyon, 7(3), e06536. https://doi.org/10.1016/j.heliyon.2021.e06536

Nurunnabi, M. (2021). The preventive strategies of COVID-19 pandemic in Saudi Arabia. Journal of Microbiology, Immunology and Infection, 54(1), 127-128. https://doi.org/10.1016/j.jmii.2020.07.023

Oraif, I., \& Elyas, T. (2021). The Impact of COVID-19 on Learning: Investigating EFL Learners' Engagement in Online Courses in Saudi Arabia. Education Sciences, 11(99), 1-19. https://doi.org/10.3390/educsci11030099

Shaibani, M. H. A. (2020). Academic Procrastination Among University Students in Saudi Arabia and Its Association with Social Media Addiction. PSYCHOLOGY AND EDUCATION, 57(8), 1118-1124.

Shin, J. K., \& Borup, J. (2020). Global Webinars for English Teachers Worldwide During a Pandemic: "They came right when I needed them the most." In R. E. Ferdig, E. Baumgartner, R. Hartshorne, R. Kaplan-Rakowski, \& C. Mouza (Eds.), Teaching, technology, and teacher education during the COVID-19 pandemic: Stories from the field (pp. 157-162). [eBook edition]. Association for the Advancement of Computing in Education.

Statista. (2020). Internet: Most common languages online 2020. Statista. Available at https://www.statista.com/statistics/262946/share-of-the-most-common-languages-on-theinternet/

Sugarman, J., \& Lazarin, M. (2020). Educating English Learners during the COVID-19 Pandemic: Policy Ideas for States and School Districts. Available at https://www.migrationpolicy.org/research/english-learners-covid-19-pandemic-policyideas 
Arab World English Journal (AWEJ) Special Issue on Covid 19 Challenges April 2021

Tashkandi, H. (2021, January 8). WhatsApp privacy changes could turn off Saudi users: Cybersecurity experts. Arab News. https://arab.news/6b3a6

ur Rahman, M. M. (2020). Challenges and Solutions of Teaching English as a Foreign Language Online During a Global Pandemic Like COVID-19: Saudi EFL Teachers' Perspectives. Journal of Southwest Jiaotong University, 55(6), 1-9. https://doi.org/10.35741/issn.02582724.55.6.10

Wheeler, S. (2012). E-Learning and Digital Learning. In N. M. Seel (Ed.), Encyclopedia of the Sciences of Learning (pp. 1109-1111). Boston, MA: Springer. https://doi.org/10.1007/978-1-4419-1428-6_431

Wiederhold, B. K. (2020). Connecting Through Technology During the Coronavirus Disease 2019 Pandemic: Avoiding "Zoom Fatigue." Cyberpsychology, Behavior, and Social Networking, 23(7), 437-438. https://doi.org/10.1089/cyber.2020.29188.bkw

Wright, S. (2021, February). How has 2020 changed academic English teaching? Cambridge Online Saudi Conference 2021. Available at https://www.cambridge.org/elt/blog/2021/02/19/hows-your-connection-academicenglish-teachers-their-responses-change/

Yandell, J. (2020). Learning under Lockdown: English teaching in the time of Covid-19.

Changing English, 27(3), 262-269. https://doi.org/10.1080/1358684X.2020.1779029 